section, Professor Kamin produces his criticisms of some of the evidence for the importance of heredity, but this section is not a reply to Eysenck's initial foray since it was evidently written without Kamin having read it. In consequence, many of Kamin's arguments are beside the point: for example, although Eysenck excludes all reference to Burt's data, now universally acknowledged - thanks to Kamin's brilliant detective work - to have been faked, Kamin devotes a chapter to attacking Burt. In the final two sections, which are much too brief, Eysenck replies to Kamin's set-piece and Kamin to Eysenck's, and there the matter rests.

No agreement is reached on which aspects of the evidence are reliable and which are not, and both authors are guilty of failing to meet the arguments adduced by the other. Thus, in his opening section Eysenck ignores many of the criticisms previously levelled by Kamin. For example, one of the strongest arguments in favour of the role of inheritance is that when monozygotic twins are brought in by foster parents, there is a higher correlation between the IQ of the natural parents and the child than between that of the foster parents and the child. Kamin has put forward two ingenious suggestions to explain this correlation in environmental terms. First, many of the foster children in question spent a year or more of their lives with their natural parents before moving to foster parents. Second, the IQ and the socio-economic status of foster parents is in general high and has much less variance than the IQ of the population at large: this reduction in environmental variance would reduce the effects of environment. One would have liked to have seen Professor Eysenck's reply to these arguments, but it is not to be found in the book. On the other hand, Eysenck points out that there is a higher correlation between the IQs of monozygotic twins reared together, but one looks in vain for Kamin's response to this argument.

Both authors give the impression of being determined to make a case and of selecting data that forward that case. It is a pity that Eysenck did not concentrate on the most solid evidence for inheritability and ignore dubious or unrepeatable findings. For example, he argues that there is a difference in the brain waves (EEGs) of the intelligent and unintelligent and that this difference suggests intelligence is inherited. Not only is the argument fallacious, since there is no reason why brain waves should not be in part determined by environmental factors, but recent attempts to repeat the finding Eysenck uses have failed.

Eysenck points out that Kamin does not have a theory of intelligence. With great ingenuity, Kamin has taken a number of pieces of evidence thought to support the hereditary case and has shown that there are other possible explanations: he has not proved that these other explanations are correct. Moreover, since Kamin treats each piece of evidence in isolation, he is able to use individual arguments that are inconsistent with one another. Thus, as Eysenck notes, Kamin explains the large differences in IQ between dizygotic twins reared together by assuming a large difference in the way they are treated within the family. Elsewhere, however, he explains the similarity in the IQs of monozygotic twins brought up apart by arguing that each pair is placed in families of a similar socioeconomic background. Taken together, Kamin's two arguments imply the absurd conclusion that there is less environmental difference between families than within a family.

There are a few things on which both authors agree. Moving children from deprived homes to particularly good homes can bring about a shift of up to 20 points in IQ. Although Kamin regards this as compelling evidence for the overriding importance of environment, Eysenck is able to show that it is consistent with his own theory of intelligence. He does not maintain that a large shift in environment cannot change IQ, merely that in conditions as they exist today IQ is more determined by heredity than environment.

Kamin does not help his case by his personal virulence towards Eysenck. The fact that Eysenck has twice made a mistake about the sex of an author whom he cites has surely nothing to do with the inheritance of IQ; and it is merely distracting to the reader for Kamin to stress past errors made by Eysenck, at least some of which (for example, his defence of Burt) Eysenck now acknowledges. Moreover, Kamin's allegation that the aim of the science of genetics is to make "the world comfortably safe for white males" is both vituperative and false - white males were a good deal safer before IQ tests were ever thought of. Eysenck rightly insists that differences in the average IQs of groups have no bearing on how the individual should be treated. It is impossible to predict the individual's IQ from skin colour, sex or social class and in at least some instances the use of objective tests for selection has favoured underprivileged groups. Burt may have been a scientific scoundrel, but his introduction of intelligence tests for secondary education in Britain between the wars doubled the proportion of poor children in secondary schools.

Like all scientific discoveries, the results of work on intelligence testing can be used for good or ill. As Eysenck notes, recent decisions by anti-racists in the United States are likely to be extremely damaging to minority groups. For example, it is folly to insist that equal proportions of blacks and whites should enter training programmes for the educationally subnormal, if, for whatever reason, a higher proportion of blacks than of whites need the help of such training. Eysenck quotes a remark of Dr Johnson's which sums up the position: when asked whether men or women were more intelligent, he replied: "Which man? Which woman?".

Intelligence: The Battle for the Mind is a wasted opportunity. One feels that had Eysenck concentrated on the most compelling arguments for the role of inheritance, and had he attempted from the outset to meet Kamin's ingenious but ad hoc arguments where they could be met and conceded cases where they could not be met, the debate might have been settled. Eysenck might not have proven that IQ is $80 \%$ inherited, but he might have established once and for all that there is a strong inherited component.

Neither combatant comments on the scientific importance of intelligence testing. A much more destructive criticism can be made of the whole enterprise than any advanced by Kamin, namely, that it has told us nothing about how the human mind works nor has it given any answer to the really important applied problem how can we make it work better?

Stuart Sutherland is Director of the Centre for Research on Perception and Cognition at the University of Sussex.

\section{Reality of science}

\section{Peter Newmark}

An Imagined World. By June Goodfield. Pp.288. ISBN 0-06-011641-2. (Harper \& Row: 1981.) \$12.95 US only.

IF A scientist wishes to discover what makes a certain type of cell tick, she may well spend five years studying its behaviour and composition. If a writer wishes to find out what makes that scientist not only tick but chime, by way of making scientific discoveries, she may decide to track the scientist's every thought throughout the five years. That neither venture is guaranteed to succeed is illustrated by this book. The story, however, is not without interest.

In 1975 June Goodfield met Anna Brito (a pseudonym) who was then on sabbatical in New York and, within hours, decided that she fitted the bill of an individual research worker through whom to follow the process of science. Goodfield found Anna Brito "articulate, amusing and somewhat different from the majority of scientists I had met before", and sensed that Brito was at a stage where doors were beginning to open. In one sense, at least, she was right. Within a year of returning from New York to Glasgow University, the doors of New York's Memorial SloanKettering Cancer Center had opened to Anna Brito. From then on Goodfield had ready access to the scientist. So except for the first year and for a period in 1977 , when progress is recounted through letters and tape recordings, the tale is told in narrative form. 
Through the letters, recordings and narrative emerges a story that illuminates the working life of a scientist in a detailed and open way that has seldom, if ever, been done before. Unlike The Double Helix, An Imagined World contains little glamour, much toil, many failures, much anguish and no prizes. It is, in a word, realistic. Whether that makes for interesting reading is a matter of taste. Certainly for the working scientist there will be few surprises, but there may be reflections, both pleasant and not so pleasant, to be seen in the mirror of Anna Brito's progress. For the non-scientist who does not realize just how great a travesty of the making of a discovery is the usual account given in a scientific paper, the book is bound to come as an eye-opener.

It would be hard, however, to claim that Anna Brito's experiences were particularly typical. Her first, and arguably most important, discovery certainly came about in an unusual way. She found herself in a London laboratory, unable to speak much English, having neither skills nor ideas to offer and altogether a rather unwanted visitor. Her supervisor, somewhat in desperation, gave her a large collection of sections of mice to examine through a microscope. Against all the odds she noticed something both original and interesting. Her observation amounted to the discovery that $T$-lymphocytes and B-lymphocytes have predilections for separate zones of tissues.

In the years that followed, Anna Brito pursued her discovery of what she called "ecotaxis" and developed the idea that certain diseases were associated with wrongly located lymphocytes. This condition she called "ecotaxopathy", a term guaranteed to turn purple the faces of many immunologists. Clearly not a lady to be thrown off course by such reactions or by what, to many, would surely be an unnerving number of grant refusals, her research continued in the same vein throughout the period covered in the book.

Much of what is recounted rings true; for example, the long periods Anna Brito spends reading around her subject hoping to place her observations into a broader context. Other features of her laboratory life seem less convincingly told. Only twice, for example, is there any mention of her having any scientific competitors. This is either true and untypical, or untrue and misleading, given the extent to which competition drives so many scientists.

The chief virtue of the book is that it recounts in detail the thoughts and actions of a scientist brave enough to be open about her mistakes and failures and to bare many of her thoughts, despite the risk that some might look naive at the time and worse in retrospect. But the book fails to shed much light on the process of scientific discovery or to sustain interest for one simple reason; as it happens, nothing that I could classify as a substantial discovery emerges during the period covered in the book.

Finally, potential readers might be attracted by two puzzles. The first, not too taxing, is the real identity of Anna Brito. The second, perplexing, is why, given the circumstances of the initial discovery that set her on the pilgrimage of research, Brito can later say: "I can't stand people who just put everything together and try to see what happens - who don't think before doing an experiment . . I I could never do science like that"?

Peter Newmark is Deputy Editor of Nature.

\section{Will the real Beaker Folk please stand up?}

\section{Colin Burgess}

The Beaker Folk: Copper Age Archaeology in Western Europe. By Richard J. Harrison. Pp.176. ISBN 0-500-02098-1. (Thames \& Hudson: 1981.) $£ 12, \$ 19.95$.

"BEAKER Folk", like the Wee Folk, exist in the mind of the beholder, and Dr Harrison is as uncertain in his attitude to "Beaker Folk" as most of us are about fairies. His last chapter, "Was there a 'Beaker Folk?'," was eminently sensible, and his conclusion that they "have no substance as a special population group", and that the Bell Beaker phenomenon began "as a fashion in fine pottery", would meet with widespread approval among students of the subject.

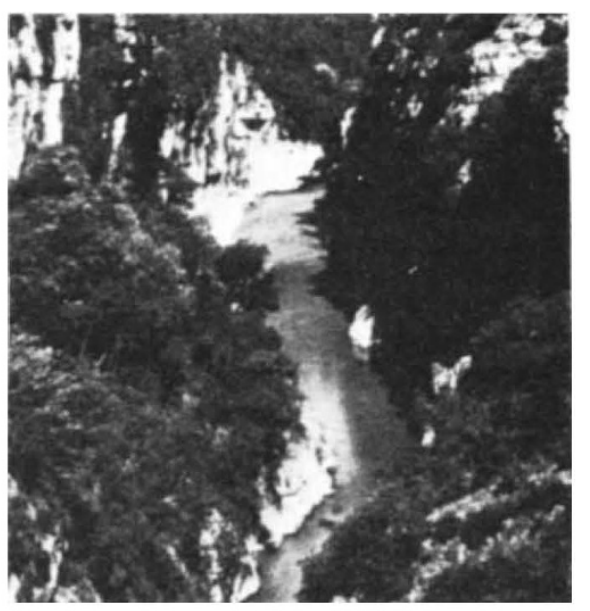

Gorge of the River Verdon in Provence, "an exceptionally interesting site',.

Unfortunately, this attitude does not square with the contradictions in his preceding six chapters. The author claims in several places not to believe in "Beaker Folk", but clearly finds it difficult to erase them from his subconscious. His inner confusion will leave the reader feeling profoundly uncomfortable, because it is obtrusive throughout: to quote from the jacket, 'the so-called 'Beaker Folk' were not a separate, well-defined community, but constituted more of an influence or movement", yet in the next sentence "They appear to have been instrumental in introducing metal technology", and their arrival "coincided with major changes in the structure of primitive society". Such ambivalence left me wondering at the end whether the author had experienced a late change of heart about "Beaker Folk", and been forced to take a scalpel to his text; or perhaps it is simply that he, like most of us, finds it difficult to adjust to a world without "Beaker Folk".

In many ways, Harrison engineers his own downfall. On p.13 he complains that "One bad habit which many archaeologists have had is to abstract beakers from their local settings and study them as something alien and isolated', which is exactly what has bedevilled study of this period in Europe, and is exactly the mistake this book perpetuates. For sadly, Harrison is largely concerned with his title, The Beaker Folk, and hardly at all with his subtitle, Copper Age Archaeology in Europe. But until the former is strictly subordinated to the latter, understanding of this exciting phase of European prehistory will advance very little.

There is a fundamental controversy about Beakers at the moment, and it should therefore be a priority in a work such as this to begin with a fair statement of the issues. As it is, for much of the book until the last chapter in fact - Harrison skates over the difficult question of Beaker interpretations with brief, throw-away allusions, and in so doing is hardly fair to those who have been trying to open up the whole question to review. For example, on p. 11 he is decidedly disparaging about the suggestion that Beakers may have been central to a beer drinking cult, but on p.15 they may "have been status symbols . . perhaps on account of a special drink", and on p.69"Bell Beakers could also have derived their importance from their contents, such as beer, mead ...'. If he looks again at what S.J. Shennan and I wrote in British Archaeological Reports in 1976 , he will see that our concern was not to set up alternative models to explain Beakers, but to show that there are explanations, other than ethnic ones, which will fit the evidence. Harrison, like some others, has seized on the evocative peyote/beer suggestion, but does not mention the equally relevant Butt Beaker analogy.

The author's preoccupation with the Beaker aspects of this phase of prehistory results in much of the book being a rather dreary regional catalogue of contexts and sites in which Beakers occur. How much more illuminating it would have been had he remembered his sub-title, and con- 